\title{
The Effect of Store Atmosphere, Promotion, and Retail Service on Customer Satisfaction and Repurchase Intention
}

\author{
Adam Hermawan Ni Nyoman Kerti Yasa \\ Faculty of Economics and Business, University of Udayana, Bali, Indonesia
}

\begin{abstract}
The purpose of this study was to examine the effect of store atmosphere, promotion, and retail service on customer satisfaction and repurchase intention, we also investigate the effect of customer satisfaction on Indomaret customer repurchase intention in Denpasar City. The population in this study were all Indomaret customers in Denpasar City, whose numbers cannot be stated or counted with certainty (infinite). Determination of the sample in this study using purposive sampling technique. The sample set in this study were 105 respondents. Data analysis in this study used path analysis with the Partial Least Square (PLS) approach. The results showed that store atmosphere, promotion, and retail service had a positive and significant effect on customer satisfaction and repurchase intention, and customer satisfaction also had a positive and significant effect on repurchase intention.
\end{abstract} Keywords: store atmosphere, promotion, retail service, satisfaction, repurchase intention

DOI: $10.7176 / \mathrm{EJBM} / 13-8-14$

Publication date: April $30^{\text {th }} 2021$

\section{Introduction}

The development of the retail business in Indonesia in the last few years is considered quite fast, due to the changing shopping patterns of Indonesians who prefer shopping in modern retail compared to traditional markets. The well-known retail stores that are widely scattered throughout Indonesia are Indomaret and Alfamart. The comparison of the results of the survey top brand award regarding retail stores in Indonesia is shown in Table 1.

Table 1.

Top Brand Award Minimarket Data

\begin{tabular}{cccccc}
\hline \multirow{2}{*}{ Brand } & TBI & TBI & TBI & TBI & TBI \\
\cline { 2 - 6 } & $(2016)$ & $(2017)$ & $(2018)$ & $(2019)$ & $(2020)$ \\
\hline Alfamart & $46.4 \%$ & $47.9 \%$ & $52.9 \%$ & $49.0 \%$ & $49,3 \%$ \\
Indomaret & $47.0 \%$ & $45.2 \%$ & $41.7 \%$ & $39.1 \%$ & $39,8 \%$ \\
\hline
\end{tabular}

Source: www.topbrand-award.com, 2021

Table 1 shows that Indomaret continues to experience a decline from 2016 to 2020 in the survey data for the top brand award. In 2016, Indomaret managed to occupy the first position with a percentage of $47.0 \%$ and managed to beat its biggest competitor, Alfamart who took second place, but in the following year Indomaret experienced a significant decrease from the previous percentage, namely to $45.2 \%$ in $2017,41.7 \%$ in 2018 , and $39.1 \%$ in 2019 , $39.3 \%$ in 2020 , this is inversely proportional to its competitors, namely Alfamart which in 2016 was under Indomaret, in 2017-2020 it was in the first position of the Top Brand Award survey defeating Indomaret, so it is interesting conducted research on Indomaret.

The success of retail can be characterized by the repurchase behavior of its customers and the retail's ability to survive in the face of its competitors so that the intention to repurchase from customers becomes the main focus when customer satisfaction has been felt. According to Ramanathan et al. (2017), customer satisfaction is the key to the success of a retail business. Customer satisfaction and repurchase intention at a retail store can be influenced by various factors including the store atmosphere, promotion, and retail service.

Sopiah and Syihabudhin (2008) state that a store must be able to form a planned atmosphere according to its target market, make visitors feel comfortable in the outlet, attract consumers while in the outlet, and can encourage consumers to make purchases. Pei et al. (2020), explain store atmosphere is an environment inside and outside the store, namely the interior in the form of lighting, color, smell, music, layout designed to influence consumers. Store atmosphere can also make customers feel happy to have hedonic value (Yistiani et al., 2012). In addition to arranging the atmosphere of its outlets, retail should carry out an intensive promotional strategy.

The promotion strategy is a marketing strategy that must be carried out by retailers. Promotion is an important element of competitive dynamics in the retail market, where retailers use a myriad of promotional techniques to attract consumers (Ma and Fildes, 2017). According to Ubeja (2014) promotion is a marketing communication process to inform, persuade, remind and influence consumers or users in supporting the sale of products or services. In-store promotion must be culturally centered because buyers demand promotion (Kashif and Rehman, 2014).

Furthermore, in addition to arranging great store atmosphere and implementing the right promotional strategy, outlet should provide the best service to customers so that customers feel satisfied. In the retail sector, satisfied customers can make customers loyal (Yuliati et al., 2014; Diputra and Yasa, 2021). Many studies have examined the positive and significant effect of customer satisfaction on customer loyalty, including Dewi et al. (2014); 
Prayoga et al. (2015); Evirasanti et al. (2016); Riasma et al. (2018); Rasmiati and Yasa (2019); Carolina and Yasa (2019); Muderawan et al. (2020); Atmadja and Yasa (2020). Creating customer satisfaction and loyalty provides a sustainable competitive advantage and differentiation from competitors. There are many factors that create customer satisfaction and loyalty in the literature, one of these factors is customer service (Kursunluoglu, 2014). Sopiah and Syihabudhin (2008) state that retail service is one of the main tools to differentiate one retail company from another retail company. The performance of retail services in accordance with customer expectations causes the retail to have a competitive advantage in the eyes of consumers, not only on satisfaction but also on customer loyalty (Lu and Seock, 2008). Based on the background and existing empirical studies, this study aims to examine and explain the influence of store atmosphere, promotions, and retail services on customer satisfaction and repurchase intention at Indomaret in Denpasar City.

\section{Research Hypothesis}

Research conducted by Chang et al. (2015) shows that consumer satisfaction is influenced by the store atmosphere, so to satisfy consumers, retailers need to ensure that they provide an attractive and pleasant shopping atmosphere. Research results by Tim and Dion (2017), Chiguvi (2017), Liaw (2017), and Pei et al. (2020), showing the results that store atmosphere has a positive and significant effect on customer satisfaction. Therefore, the study proposed the hypothesis:

H1: Store atmosphere has a positive and significant effect on customer satisfaction

Research by Ghezelbash (2017) shows that promotion has a positive and significant effect on customer satisfaction. In line with the research of San and Aryupong (2017), Nakarmi and Koski (2018) obtained the results that promotion, especially the promotion mix, is an important factor in marketing that has a positive and significant effect on customer satisfaction. Based on the results of the empirical study, the hypothesis is proposed:

$\mathrm{H} 2$ : Promotion has a positive and significant effect on customer satisfaction

Mahfooz's (2014) research results show that there is a significant relationship between the dimensions of retail service quality (physical aspects, reliability, personal interaction, problem-solving, and policy) and customer satisfaction. These results are in line with the research of Minh and Hun (2016); Pei et al. (2020); and Chopra (2014) who obtained the results that retail services have an important role in increasing customer satisfaction. Hence, the hypothesis is proposed:

H3: Retail services have a positive and significant effect on customer satisfaction

The research by $\mathrm{Wu}$ and Chung (2016) found that there was a significant effect of store atmosphere on consumer repurchase intentions. In line with the research of Huang and Dang (2014), Apriliani and Giantari (2015), Jalil et al., (2016), Wandira and Nugroho (2016), Nirwana et al. (2016) concluded that store atmosphere has a positive and significant effect on customer satisfaction, the following hypothesis can be proposed:

H4: Store atmosphere has a positive and significant effect on repurchase intention

Research conducted by Tanjung and Setiomuliono (2016) concluded that price promotions have a positive and significant effect on repurchase intention. A similar study by Huang et al. (2014), Wu and Chung (2016), Sachse and Massera (2018), Yudha and Suprapti (2018) conclude that the attractiveness of sales promotions has a positive and significant effect on repurchase intentions, which means that the more attractive sales promotions conducted by Matahari Mall Bali Galeria, the higher the customer's repurchase intention, the research hypothesis can be formulated as follows:

H5: Promotion has a positive and significant effect on repurchase intention

Research conducted by Santikayasa and Santika (2019) concluded that service quality has a positive and significant effect on repurchase intention. In line with the research of Cho (2015), Baskol (2016), Nilsson and Wall (2017) also obtained the results that the consumer experience in the form of good retail service has an important role in increasing consumer repurchase intention at retail stores. Therefore, the study proposed the hypothesis:

H6: Retail services have a positive and significant effect on repurchase intention

The results of research conducted by Elbeltagi and Agag (2016) show that the customer satisfaction variable has a direct positive effect on repurchase intention. These results are consistent with the results of research by Han et al. (2018) show that customer satisfaction has a positive and significant effect on repurchase intention. Similar research by Saidani and Arifin (2012); Chopra (2014); Jalil et al. (2016); Nilsson and Wall (2017); and Diputra and Yasa (2021), also found that consumer satisfaction has a positive effect directly or indirectly on consumer repurchase intentions, so the following research hypothesis can be formulated:

H7: Customer satisfaction has a positive and significant effect on repurchase intention

Based on the introduction and previous research studies, the conceptual framework in this study is presented in Figure 1. 


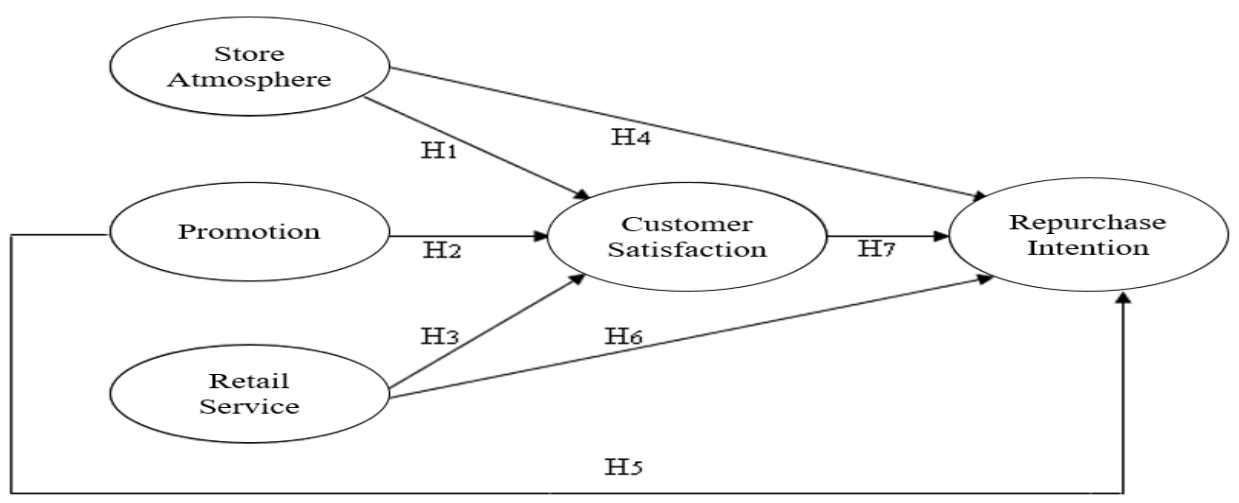

Figure 1 Conceptual Framework Model

\section{Research Methods}

This research was conducted in Denpasar City, with the consideration that there are 24 Indomaret outlets in Denpasar City so that Indomaret in Denpasar City can be categorized as modern retail that has a broad target market. The object of this research is the influence of outlet atmosphere, promotions, and retail services on customer satisfaction and customer repurchase intentions.

The population in this study were all Indomaret customers in Denpasar City, whose numbers cannot be stated or counted with certainty (infinite). Determination of the sample in this study using purposive sampling technique. The number of sample members or the sample size specified in this study were 105 respondents with the consideration that the sample size was $5 \times$ the number of indicators $(5 \times 21$ indicators $=105$ respondents). The criteria used to determine the sample members in this study are customers who have shopped at Indomaret outlets in the Denpasar City area more than once in a year and have over 17 years of age because they have can understand and fill out questionnaires. The collected questionnaires are then recapitulated in the MS. Excel excel, then analyzed using the Partial Least Square (PLS) approach. The exogenous variables of this study are store atmosphere $\left(\mathrm{X}_{1}\right)$, promotion $\left(\mathrm{X}_{2}\right)$ and retail service $\left(\mathrm{X}_{3}\right)$, while the endogenous variables are customer satisfaction $\left(\mathrm{Y}_{1}\right)$ and repurchase intention $\left(\mathrm{Y}_{2}\right)$.

\section{Results And Discussion}

The profiles of respondents in the study were 105 respondents, based on the criteria: store area, gender, age, occupation, education, and frequency of shopping. The characteristics of the respondents can be seen in Table 2 .

\section{Table 2}

Characteristics of Respondents

\begin{tabular}{|c|c|c|c|c|}
\hline No & Variable & Classification & Frequency & Percentage $(\%)$ \\
\hline \multirow[t]{5}{*}{1} & Store Area & Denpasar Barat & 32 & 30.5 \\
\hline & & Denpasar Selatan & 32 & 30.5 \\
\hline & & Denpasar Timur & 20 & 19.0 \\
\hline & & Denpasar Utara & 21 & 20.0 \\
\hline & & & 105 & 100.0 \\
\hline \multirow[t]{3}{*}{2} & Gender & Male & 55 & 52.4 \\
\hline & & Female & 50 & 47.6 \\
\hline & & & 105 & 100.0 \\
\hline \multirow[t]{4}{*}{3} & & $17-26$ & 61 & 58.1 \\
\hline & Age & $27-36$ & 23 & 21.9 \\
\hline & & $37-46$ & 21 & 20.0 \\
\hline & & & 105 & 100.0 \\
\hline \multirow[t]{5}{*}{4} & Occupation & Student & 25 & 23.8 \\
\hline & & Private employees & 51 & 48.6 \\
\hline & & Civil servants & 10 & 9.5 \\
\hline & & Entrepreneur & 19 & 18.1 \\
\hline & & & 105 & 100.0 \\
\hline \multirow[t]{4}{*}{5} & & Associate Degree & 12 & 11.4 \\
\hline & Education & Bachelor's/ Master's Degree & 54 & 51.4 \\
\hline & & High school & 39 & 37.1 \\
\hline & & & 105 & 100.0 \\
\hline
\end{tabular}




\begin{tabular}{ccccc}
\hline No & Variable & Classification & Frequency & Percentage (\%) \\
\hline \multirow{2}{*}{6} & & $>6$ times & 37 & 35.2 \\
\cline { 3 - 5 } & Frequency of & $1-3$ times & 43 & 41.0 \\
\cline { 2 - 4 } & Shopping & $4-5$ times & 25 & 23.8 \\
\hline & & $\mathbf{1 0 5}$ & $\mathbf{1 0 0 . 0}$ \\
\hline
\end{tabular}

Source: Primary data, 2021

The data shows that the majority of customers who have shopped at Indomaret outlets who were respondents in this study made purchases at Indomaret, which are in the areas of West and South Denpasar City. The majority of Indomaret customers who were respondents in this study were men, with the majority of the age range between 17-26 years old who were graduates who already had jobs. When viewed based on the respondent's occupation, the data shows that the dominant respondent has a job as a private employee. Respondents who work as private employees tend to have income and have a high level of mobility to work, so that respondents often do shopping activities in Indomaret. In addition, the majority of respondents tend to do shopping activities in Indomaret with the frequency of shopping at Indomaret outlets in Denpasar City in a month as much as 1 to 3 times.

The results of the correlation between the indicators and their variables can be seen in the convergent validity output in Table 3 below.

Table 3.

Convergent Validity Test Results

\begin{tabular}{|c|c|c|}
\hline Variable & Indicator & Outer Loadings \\
\hline \multirow{8}{*}{ Store Atmosphere } & $\mathrm{X}_{1.1}$ & 0,739 \\
\hline & $\mathrm{X}_{1.2}$ & 0,861 \\
\hline & $\mathrm{X}_{1.3}$ & 0,809 \\
\hline & $\mathrm{X}_{1.4}$ & 0,811 \\
\hline & $\mathrm{X}_{1.5}$ & 0,809 \\
\hline & $\mathrm{X}_{1.6}$ & 0,873 \\
\hline & $\mathrm{X}_{1.7}$ & 0,860 \\
\hline & $\mathrm{X}_{1.8}$ & 0,815 \\
\hline \multirow{3}{*}{ Promotion } & $\mathrm{X}_{2.1}$ & 0,881 \\
\hline & $\mathrm{X}_{2.2}$ & 0,892 \\
\hline & $\mathrm{X}_{2.3}$ & 0,877 \\
\hline \multirow{3}{*}{ Retail Service } & $\mathrm{X}_{3.1}$ & 0,912 \\
\hline & $\mathrm{X}_{3.2}$ & 0,836 \\
\hline & $\mathrm{X}_{3.3}$ & 0,892 \\
\hline \multirow{4}{*}{ Customer Satisfaction } & $\mathrm{Y}_{1.1}$ & 0,844 \\
\hline & $\mathrm{Y}_{1.2}$ & 0,826 \\
\hline & $\mathrm{Y}_{1.3}$ & 0,768 \\
\hline & $\mathrm{Y}_{1.4}$ & 0,827 \\
\hline \multirow{3}{*}{ Repurchase Intention } & $\mathrm{Y}_{2.1}$ & 0,887 \\
\hline & $\mathrm{Y}_{2.2}$ & 0,865 \\
\hline & $\mathrm{Y}_{2.3}$ & 0,821 \\
\hline
\end{tabular}

Source: Data Processed Results, 2021

The results of the convergent validity test in Table 3 show that all values of the outer loading variable indicator have a value greater than 0.50 with a $p$ value of 0.000 less than 0.05 . Thus, it can be concluded that all indicators have met the requirements for convergent validity. Furthermore, the discriminant validity test is shown in Table 4. 
Tabel 4.

Results of Discriminant Validity

\begin{tabular}{|c|c|c|c|c|c|c|c|}
\hline \multirow[b]{2}{*}{ Variable } & \multirow[b]{2}{*}{ AVE } & \multirow[b]{2}{*}{ RSAVE } & \multicolumn{5}{|c|}{ Correlation } \\
\hline & & & $\begin{array}{c}\text { Store } \\
\text { atmosphere } \\
\left(\mathrm{X}_{1}\right) \\
\end{array}$ & $\begin{array}{c}\text { Promotion } \\
\left(\mathbf{X}_{2}\right)\end{array}$ & $\begin{array}{c}\text { Retail } \\
\text { service } \\
\left(\mathbf{X}_{3}\right) \\
\end{array}$ & $\begin{array}{c}\text { Customer } \\
\text { satisfaction } \\
\left(Y_{1}\right) \\
\end{array}$ & $\begin{array}{c}\text { Repurchase } \\
\text { intention } \\
\left(Y_{2}\right) \\
\end{array}$ \\
\hline Store atmosphere $\left(\mathrm{X}_{1}\right)$ & 0,677 & 0,823 & 1,000 & & & & \\
\hline Promotion $\left(\mathrm{X}_{2}\right)$ & 0,781 & 0,883 & 0,736 & 1,000 & & & \\
\hline Retail service $\left(\mathrm{X}_{3}\right)$ & 0,776 & 0,881 & 0,645 & 0,725 & 1,000 & & \\
\hline $\begin{array}{l}\text { Customer satisfaction } \\
\left(\mathrm{Y}_{1}\right)\end{array}$ & 0,668 & 0,817 & 0,695 & 0,717 & 0,682 & 1,000 & \\
\hline $\begin{array}{l}\text { Repurchase intention } \\
\left(\mathrm{Y}_{2}\right)\end{array}$ & 0,736 & 0,858 & 0,798 & 0,813 & 0,753 & 0,767 & 1,000 \\
\hline
\end{tabular}

Source: Data Processed Results, 2021

Table 5 shows all variables meet the criteria for discriminant validity, because the AVE value of all variables is greater than 0.50 so that the model is valid. Besides the validity test, the variable reliability test was also carried out with the following results.

Tabel 5.

Instrument Reliability Test Results

\begin{tabular}{lcc}
\hline \multicolumn{1}{c}{ Variabel } & Composite Reliability & Cronbach's Alpha \\
\hline Store atmosphere $\left(\mathrm{X}_{1}\right)$ & 0,944 & 0,932 \\
\hline Promotion $\left(\mathrm{X}_{2}\right)$ & 0,914 & 0,859 \\
\hline Retail service $\left(\mathrm{X}_{3}\right)$ & 0,912 & 0,855 \\
\hline Customer satisfaction $\left(\mathrm{Y}_{1}\right)$ & 0,889 & 0,835 \\
\hline Repurchase intention $\left(\mathrm{Y}_{2}\right)$ & 0,893 & 0,820
\end{tabular}

Source: Data Processed Results, 2021

The results of the composite reliability and Cronbachs alpha output variables for store atmosphere, promotion, retail service, customer satisfaction, and repurchase intention were all above 0.70 . Thus, it can be explained that all variables are reliable.

Tabel 6.

R-square Value of Endogenous Variable

\begin{tabular}{cccc}
\hline \multicolumn{1}{c}{ Stuctural Model } & Endogenous Variable & R-square & $\begin{array}{c}\text { Adjusted } \\
\text { R-square }\end{array}$ \\
\hline 1 & \multicolumn{1}{c}{ Customer satisfaction $\left(\mathrm{Y}_{1}\right)$} & 0,608 & 0,597 \\
\hline 2 & Repurchase intention $\left(\mathrm{Y}_{2}\right)$ & 0,794 & 0,786 \\
\hline Calculation: $\mathrm{Q}^{2}$ & $=1-\left(1-\left(\mathrm{R}_{1}{ }^{2}\right)\right)\left(1-\left(\mathrm{R}_{2}{ }^{2}\right)\right)$ & & \\
& $=1-(1-0,608)(1-0,794)$ & & \\
& $=1-(0,392)(0,206)$ & & \\
& $=1-0,0807$ \\
& $=0,9193$ & & \\
\hline
\end{tabular}

Source: Data Processed Results, 2021

Based on Table 6, the model of the influence of store atmosphere, promotions, and retail services on customer satisfaction provides an R-square value of 0.608 which can be interpreted that the variability of customer satisfaction variables can be explained by the variability of store atmosphere variables, promotions, and retail services by 60.8 percent, while the remaining 39.2 percent is explained by other variables outside the model. Furthermore, the model of the influence of store atmosphere, promotions, retail services and customer satisfaction on repurchase intentions provides an R-square value of 0.794 which can be interpreted that the variability of the repurchase intention variable can be explained by the variability of the store atmosphere, promotion, retail service and customer satisfaction variables by 79.4 percent, while the remaining 20.6 percent is explained by other variables outside the model. The results of these calculations show that the Q-square value is 0.9193, so it can be concluded that the model has great predictive relevance. Thus, it can be explained that 91.93 percent of the variation in repurchase intention is influenced by store atmosphere, promotions, retail services and customer satisfaction, while the remaining 8.07 percent is influenced by other variables.

This study uses a Partial Least Square (PLS) analysis approach to test the research hypotheses. The results of the analysis of the empirical research model using Partial Least Square (PLS) analysis can be seen in Figure 2 below. 


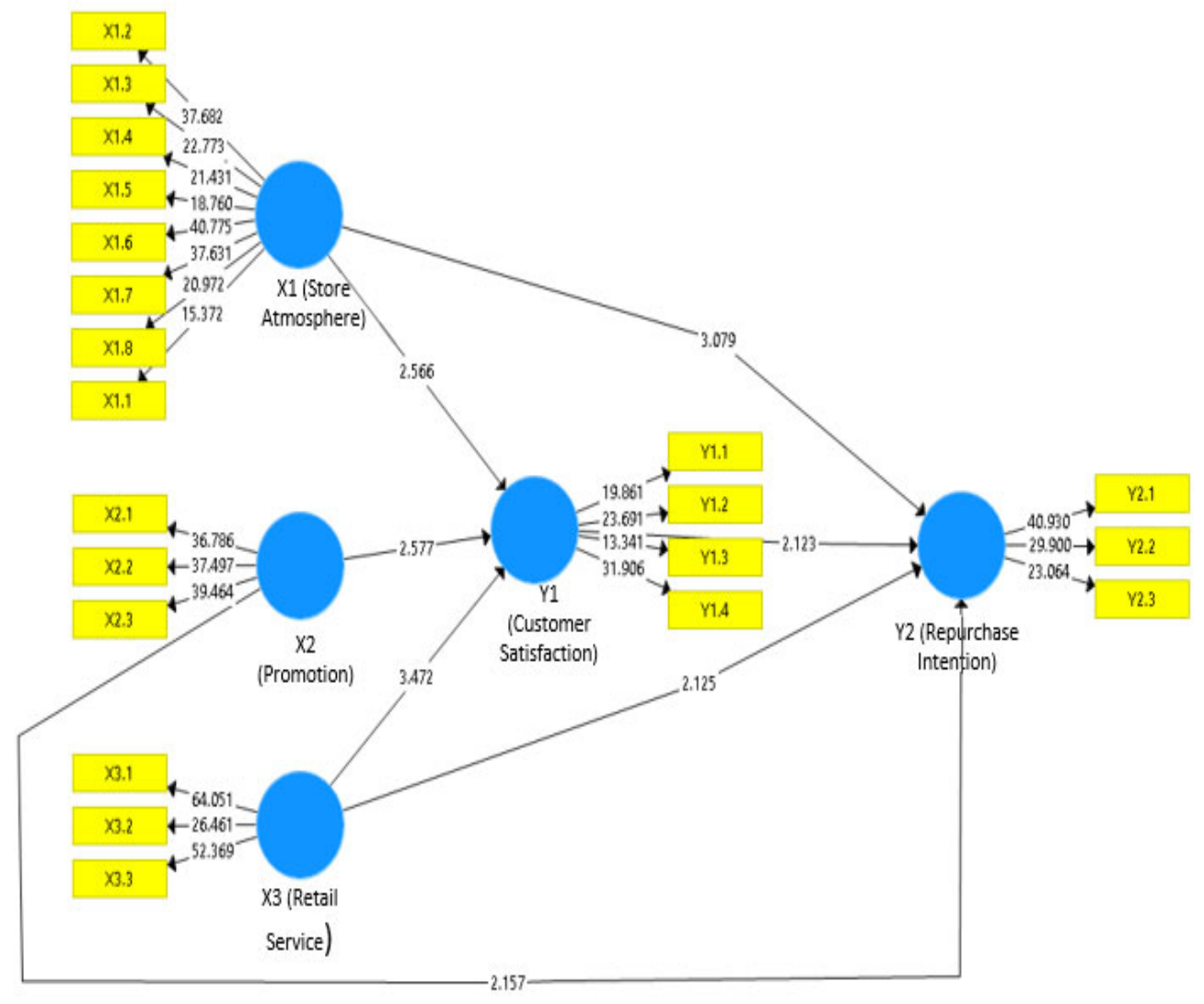

Source: Data Processed Results, 2021

Figure 2. Empirical PLS Algorithm Model below.

The results of the path coefficient validation test on each path for direct effect can be presented in Table 7

Direct Effect Test Results (Path Coefficient)

\begin{tabular}{cllcccc}
\hline No. & \multicolumn{2}{c}{ Relations Between Variables } & $\begin{array}{l}\text { Path Coefficient } \\
\text { (Bootstrapping) }\end{array}$ & $\begin{array}{c}\text { t } \\
\text { Statistic }\end{array}$ & $\begin{array}{c}\text { P } \\
\text { Value }\end{array}$ & Result \\
\hline $\mathbf{1}$ & $\begin{array}{l}\text { Store Atmosphere } \\
\text { Satisfaction (Y1) }\end{array}$ & $\rightarrow$ Customer & 0,298 & 2,566 & 0,011 & Significant \\
\hline $\mathbf{2}$ & $\begin{array}{l}\text { Store Atmosphere } \\
\text { Intention (Y2) }\end{array} \rightarrow$ Repurchase & 0,313 & 3,079 & 0,002 & Significant \\
\hline $\mathbf{3}$ & Promotion (X2) $\rightarrow$ Customer Satisfaction (Y1) & 0,301 & 2,577 & 0,010 & Significant \\
\hline $\mathbf{4}$ & Promotion (X2) $\rightarrow$ Repurchase Intention (Y2) & 0,289 & 2,157 & 0,031 & Significant \\
\hline $\mathbf{5}$ & $\begin{array}{l}\text { Retail Service (X3) } \rightarrow \text { Customer Satisfaction } \\
\text { (Y3) }\end{array}$ & 0,272 & 3,472 & 0,001 & Significant \\
\hline $\mathbf{6}$ & $\begin{array}{l}\text { Retail Servive (X3) } \rightarrow \text { Repurchase Intention } \\
\text { (Y2) }\end{array}$ & 0,203 & 2,125 & 0,034 & Significant \\
\hline $\mathbf{7}$ & $\begin{array}{l}\text { Customer Satisfaction (Y1) } \rightarrow \text { Repurchase } \\
\text { Intention (Y2) }\end{array}$ & 0,203 & 2,123 & 0,034 & Significant \\
\hline Sourt
\end{tabular}

Source: Data Processed Results, 2021

Store atmosphere is proven to have a positive and significant effect on customer satisfaction. This result is indicated by a positive path coefficient of 0.298 with a t-statistic of 2.566 (t-statistic $>1.96$ ), thus, hypothesis 1 (H1) is accepted. This means that the better the condition of the store atmosphere at the Indomaret outlet, the higher the customer satisfaction at the Indomaret. Nevertheless, other studies report similar findings. Chiguvi (2017), Liaw (2017) and Pei et al. (2020) who obtained the results that store atmosphere has a positive and significant effect on customer satisfaction.

Store atmosphere has been shown to have a positive and significant effect on repurchase intentions. This result is indicated by a positive path coefficient of 0.224 with a t-statistic of 3.079 (t-statistic $>1.96$ ), thus, hypothesis 2 (H2) is accepted. This means that the better the condition of the store atmosphere at Indomaret, the 
more it will increase the customer's repurchase intention. The result was consistent with the study from Wu and Chung (2016) which found that there was a significant impact of store atmosphere on consumer repurchase intentions in Taiwan. This is also consistent with the research results of Jalil et al. (2016) and Huang and Dang (2014) who obtained the results that the store environment has a positive influence on consumer repurchase intentions.

Promotion is proven to have a positive and significant effect on customer satisfaction. This result is indicated by a positive path coefficient of 0.448 with a t-statistic of 2.577 (t-statistic $>1.96$ ), thus, hypothesis 3 (H3) can be proven. This means that the more attractive the promotions provided by Indomaret, the higher the customer satisfaction at Indomaret. The results of this study consistent with the research of Ghezelbash (2017), San and Aryupong (2017), Nakarmi and Koski (2018) which found that promotion is an important factor in marketing that has a positive influence on customer satisfaction.

Promotion is proven to have a positive and significant effect on repurchase intention. This result is indicated by a positive path coefficient of 0.289 with a t-statistic of 2.157 (t-statistic $>1.96$ ), thus hypothesis 4 (H4) is accepted. This means that the more attractive the promotions given by Indomaret, the higher the repurchase intention at Indomaret. This study supports the results of a study conducted by Huang et al. (2014) who explained that Starbucks price promotion activities in Taiwan showed a significant direct effect on repurchase intentions. This research is in accordance with the study of Wu and Chung (2016) which found that promotion has a positive and significant correlation to consumer repurchase intentions in Taiwan. This is also in line with the research of Huang and Dang (2014) and Sachse and Massera (2018) which state that price promotions and promotion intensity have a significant effect on increasing consumer repurchase intentions.

Retail services are proven to have a positive and significant effect on customer satisfaction. This result is indicated by a positive path coefficient of 0.272 with a t-statistic of 3.472 (t-statistic $>1.96$ ), thus, hypothesis 5 (H5) is accepted. This means that the better the retail services provided by Indomaret, the higher the customer satisfaction at Indomaret. The results of this study are in accordance with the research of Pei et al. (2020), Minh and Hun (2016), Mahfooz (2014) and Chopra (2014) who obtained the results that retail services have an important role in increasing customer satisfaction.

Retail services are proven to have a positive and significant effect on repurchase intentions. This result is indicated by a positive path coefficient of 0.203 with a t-statistic of 2.125 (t-statistic $>1.96$ ), thus, hypothesis 6 (H6) is accepted. This means that the better the retail services provided by Indomaret, the higher the repurchase intention at Indomaret. This study is in accordance with the results of research by Cho (2015) who researched in Canada, which found that service had a positive effect on consumer repurchase intention. It is also in line with the research of Wibowo (2015), Baskol (2016), Nilsson and Wall (2017) and Santikayasa and Santika (2019) which obtained results that service has an important role in increasing consumer repurchase intentions, namely the better the quality of service, the better the purchase intention.

Customer satisfaction is proven to have a positive and significant effect on repurchase intention. This result is indicated by a positive path coefficient of 0.203 with a t-statistic of 2.123 (t-statistic $>1.96$ ), thus, hypothesis 7 (H7) can be proven. The results obtained can be interpreted that the higher the level of customer satisfaction, then the consumer's repurchase intention will increase. This means that the higher the customer satisfaction at Indomaret outlets, the higher the repurchase intention at the Indomaret. This study is in accordance with the results of research by Nilsson and Wall (2017) which found that customer satisfaction with service when shopping can increase consumer repurchase intentions at online clothing retail stores in Sweden. Research by Chopra (2014); Jalil et al. (2016); and Diputra and Yasa (2021), also found that consumer satisfaction has a positive effect directly or indirectly on consumer repurchase intentions.

The results showed that there was a positive and significant relationship between the variables of store atmosphere, promotion, and retail services on customer satisfaction, and customer satisfaction had a positive and significant effect on repurchase intention. The implication of the research results is in accordance with the application of Theory of Planned Behavior (TPB), where this theory states that consumer attitudes can affect consumer intentions to behave, namely in this study customer satisfaction attitudes are influenced by several factors consisting of store atmosphere, promotion and retail services, and able to form consumer repurchase intentions at Indomaret outlets.

This research has implications for Indomaret as a material for consideration and evaluation of consumer satisfaction at Indomaret outlets and consumer repurchase intentions at Indomaret outlets and the factors that influence it. Indomaret management in increasing consumer repurchase intentions should be able to see and consider factors such as store atmosphere, promotions, and retail services because these can significantly influence customer satisfaction and consumer repurchase intentions at Indomaret outlets.

\section{Conclusions And Suggestions For Future Research}

The conclusions of this research are 1) Store atmosphere has a positive and significant effect on customer satisfaction; 2) Promotion has a positive and significant effect on customer satisfaction; 3) Retail services have a 
positive and significant effect on customer satisfaction; 4) Store atmosphere has a positive and significant effect on repurchase intention; 5) Promotion has a positive and significant effect on repurchase intention; 6) Retail services have a positive and significant effect on repurchase intentions; and 7) Customer satisfaction has a positive and significant effect on repurchase intention.

Suggestions that can be given are based on the research results, namely to improve the perception of store atmosphere in customers, so Indomaret should be able to play comfortable music for its customers when shopping at Indomaret. Efforts that can be made by the management of Indomaret to improve the quality of its promotion are by providing a catalog to inform new products and various discounts offered as well as providing prizes for purchasing certain products for its customers. Then the efforts that can be made by Indomaret management to improve the quality of its retail services are by providing training for employees so that employees of Indomaret outlets in Denpasar City can serve customers in a friendly and optimal manner. Indomaret in Denpasar City can also increase customer satisfaction by increasing the quality of the facilities provided in Indomaret outlets.

Future research is suggested to examine other variables that affect satisfaction and repurchase intention, for example by adding a variable company image, word of mouth, or other variables.

\section{References}

Apriliani, N.P.D.A dan Giantari, I.G.A.K. (2015). Pengaruh Suasana Toko dan Lokasi Terhadap Niat Beli Ulang Konsumen di Minimarket Sekawan Tabanan, E-Jurnal Manajemen Unud, 4 (2), pp: 372 - 383

Atmadja, Gede Karmeita Kusuma and Yasa, Ni Nyoman Kerti. (2020). The Role of Customer Satisfaction in Mediating the Influence of Price Fairness and Service Quality on the Loyalty of Low Cost Carriers Customers in Indonesia, International Research Journal of Management, IT \& Social Sciences, 7 (5), pp. 149-159.

Baskol, Melih. (2016). The Effects of E-Retail Service Quality on Repurchase Intention. Business and Economics Research Journal, 7 (4), pp.107-121.

Carolina, Deby and Yasa, Ni Nyoman Kerti. (2019). The Effect Of Customer Relationship Management On The Satisfaction To Build Customers' Loyalty. Journal of Business and Management Research (JOBMER), 3 (5), pp. 9-20.

Chang, H.J., Cho, H.J., Turner, T., Gupta, M. and Watchravesringkan, K. (2015). Effects of store attributes on retail patronage behaviors: Evidence from activewear specialty stores. Journal of Fashion Marketing and Management, 19 (2), pp. 136-153.

Chopra, Komal. (2014). Empirical study on role of customer service in delivering satisfaction at branded retail outlets in Pune. Procedia Economics and Finance, 11, pp: $239-246$

Chiguvi, Douglas. (2015). Impact of Ambiance Conditions on Customer Satisfaction in the Restaurant Industry; Case Study of Debonairs Pizza Outlets in Botswana. International Journal of Science and Research (IJSR). 6 (2), pp: $1825-1833$

Cho, Yun Kyung. (2015). Creating customer repurchase intention in Internet retailing: The effects of multiple service events and product type. Journal of Retailing and Consumer Services. 22, pp. 213-222

Diputra, I G.N.A.W. Maha and Yasa, Ni Nyoman Kerti. (2021), The Influence Of Product Quality, Brand Image, Brand Trust On Customer Satisfaction And Loyalty, American International Journal of Business Management, 4 (1), pp. 25-34.

Dewi, G, Yasa, Ni Nyoman Kerti, Sukaatmadja, IPG, (2014). Pengaruh Kualitas Pelayanan Terhadap Kepuasan dan Loyalitas Nasabah Pada PT BPR Hoki di Kabupaten Tabanan, E- Jurnal Ekonomi dan Bisnis Universitas Udayana, 3 (5), hal: 257-275.

Elbeltagi, Ibrahim dan Agag, Gomaa. (2016). E-retailing ethics and its impact on customer satisfaction and repurchase intention: A cultural and commitment-trust theory perspective. Internet Research. 26 (1), pp. 288310

Evirasanti, Meyta Made, Rahyuda, K, Yasa, Ni Nyoman Kerti, (2016). Pengaruh Kualitas Makanan, Kualitas Layanan, dan Lingkungan Fisik Terhadap Kepuasan dan Behavioral Intentions, E-Jurnal Ekonomi dan Bisnis Unud, 5 (12).

Ghezelbash, Shekoufeh., dan Hussein Khodadadi. (2017). Evaluating the Impact of Promotion Price, Product Quality, Service Quality, Customer Satisfaction and Repeating Purchase Incentives (Case Study: Amiran Chain Stores). Journal of Internet Banking and Commerce.

Han, H., Lee, M.J. and Kim, W. (2018). Role of shopping quality, hedonic/utilitarian shopping experiences, trust, satisfaction and perceived barriers in triggering customer post-purchase intentions at airports. International Journal of Contemporary Hospitality Management. 30 (10), pp. 3059-3082.

Hendro, Yulianto Eko., Yulianto Edy., dan Wilopo. (2013). Pengaruh retail marketing mix terhadap keputusan pembelian tidak terencana pada pusat perbelanjaan. (Survei Pada Konsumen Matahari Department Store Cabang Matos). Jurnal Administrasi Bisnis.

Huang, Y.F., and Dang, H.S. (2014). An Empirical Analysis on Purchase Intention on Coffee Beverage in Taiwan. European Journal of Business and Managemen. 6 (36), pp: 182-196 
Jalil, N.A.A., A. Fikry dan A. Zainuddin. (2016). The Impact of Store Atmospherics, Perceived Value, and Customer Satisfaction on Behavioural Intention. Procedia Economics and Finance, 37, pp: 538 - 544

Kashif, Muhammad., dan Rehman, Mohsin Abdul. (2014). Expected service quality of utility stores in Pakistan. International Journal of Quality and Service Sciences, 6 (4), pp. 309 - 325

Kursunluoglu, Emel. (2014). Shopping centre customer service: creating customer satisfaction and loyalty. Journal Marketing Intelligence and Planning. 32 (4), pp. 528-548

$\mathrm{Lu}, \mathrm{Y}$., and Seock, Y. (2008). The influence of grey consumers service quality perception on satisfaction and store loyalty behavior. Internasional Journal of Retail \& Distribution Management. 36, pp: 907-918

Ma, Shauhui., dan Fildes, Robert. (2017). A retail store SKU promotions optimization model for category multiperiod profit maximization. European Journal of Operational Research, 26 (2), pp. 680 - 692.

Mahfooz, Y. (2014). Relationship between Service Quality and Customer Satisfaction in Hypermarkets of Saudi Arabia. International Journal of Marketing Studies, 6 (4), pp. 10-23.

Minh, Ngo Vu., and Nguyen Huan Huu. (2016). The Relationship between Service Quality, Customer Satisfaction and Customer Loyalty: An Investigation in Vietnamese Retail Banking Sector. Journal of Competitiveness, 8 (2), pp. $103-116$.

Muderawan, Ayu Natya, Rahanata, Gede Bayu, Yasa, Ni Nyoman Kerti. (2020). Building Customer Loyalty Through Customer Satisfaction that Influenced by Promotion, Trust and Perceived Ease of Use, American Journal of Humanities and Social Science Research, 4 (11), pp. 102-112.

Nakarmi, Anuraj., and Miia Koski. (2018). Effect Of Sales Promotion On Consumer Behavior. Journal International Business. pp: 1-44

Nilsson, Johanna., and Olle Wall. (2017). Online Customer Experience, Satisfaction, and, Repurchase Intention for Online Clothing Retailing. Journal Business, Economics, and Law. pp: 1-23

Nirwana, Muhammad Azis, Paramita, Patricia Dhiana, dan Wulan, Heru Sri Wulan. (2016). Influence Store Atmopshere and Quality of Service for Customer Satisfaction That Influence Repurchase Itention In Boutique Mounira Semarang. Journal of Management. 2.(2).

Prayoga, Surya, Yasa, Ni Nyoman Kerti, Wardana, Made. (2015). Relational Benefit, Kepuasan, dan Loyalitas Pelanggan Pada Bengkel Pada PT Dewata Honda Motor, Jurnal Manajemen dan Kewirausahaan, 17 (1).

Pei, Xue-Liang., Jia-Ning Guo, Tung-Ju Wu, Wen-Xin Zhou, and Shang-Pao Yeh. (2020). Does the Effect of Customer Experience on Customer Satisfaction Create a Sustainable Competitive Advantage? A Comparative Study of Different Shopping Situations. Sustainability, 12 (7436), pp. 1-19

Ramanathan, Usha., Subramanian, Nachiappan., dan Parrott, Guy. (2017). Role of social media in retail network operations and marketing to enhance customer satisfaction. International Journal of Operations \& Production Management, 37 (1), pp.105-123.

Rasmiati, Dwi and Yasa, Ni Nyoman Kerti. (2019). The Effect Of Retail Service And Store Image On Customer Satisfaction And Loyalty In Nirmala Supermarket Jimbaran-Bali, European Journal of Business, Economics and Accountancy, 7 (3), pp. 38-52.

Riasma, DKP, Rahyuda, I Ketut, Yasa, Ni Nyoman Kerti. (2018) The Role Of Satisfaction And Trust In Mediating The Relationship Of Brand Experience And Loyalty (A Study On Consumers Of Hilo Brand Milk Product, International Journal of Economic, Commerce and Management (IJECM), VI (1), pp. 66-77.

Sachse, Silke Bambauer and Laura Massera. (2018). Effects of price promotions on purchase intentions in postpromotion periods. Jurnal Die Unternehmung, 72 (2), pp: 126-145

Saidani, B. dan Arifin, S. (2012). Pengaruh Kualitas Produk Dan Kualitas Layanan Terhadap Kepuasan Konsumen Dan Minat Beli Pada Ranch Market. Jurnal Riset Manajemen Sains Indonesia (JRMSI). 3 (1).

San, Nann Ei Ei., and Mayuree Aryupong. (2020). Effects of Sales Promotional Tools on Product Quality, Brand Image, and Customer Satisfaction. The Application of Inverted U-Shaped Theory. Jurnal Bisnis Review. 12 (1). pp: 84-103.

Santikayasa, I Made Ari dan Santika, I Wayan. (2019). Peran Citra Toko Dalam Memediasi Pengaruh Kualitas Pelayanan Terhadap Niat Beli Ulang Konsumen. E-Jurnal Manajemen. 8 (2), pp: 8104 - 8134

Sopiah dan Syihabuddin. (2008). Manajemen Bisnis Ritel. Yogyakarta : ANDI

Tanjung, Felix dan Setiomuliono, Michael. (2016), Analisis Pengaruh Promosi Harga Terhadap Minat Beli Ulang Dengan Kepuasan Sebagai Variabel Perantara Di De Boliva Surabaya Town Square. Journal Hospitality dan Manajemen jasa. 46 (1).

Tim, Lili dan Dion, Dewa Barata. (2017). Pengaruh Atmosfer Gerai, Promosi Penjualan dan Pelayanan Ritel terhadap Kepuasan Pelanggan dan Dampaknya terhadap Loyalitas Pelanggan Ritel di Lotte Mart Kelapa Gading. Jurnal Bisnis dan Komunikasi. Kalbisocio, 4 (1).

Ubeja, Satnam. (2014). A Study of Sales Promotion Mix on Customer Satisfaction With Reference to Shopping Malls in Indore Global. Journal of Finance and Management. 6 (3), pp: 245-252

https://www.topbrand-award.com/top-brand-index (diakses 21 Februari 2021)

Wandira, K. R. dan Nugroho, D.A. (2016). Pengaruh Suasana Toko dan Pengaruh Sosial Terhadap Minat 
Pembelian Ulang Pelanggan Pada Lai-Lai Market Buah dan Sayur dengan Kepuasan Pelanggan sebagai Variabel Intervening. Jurnal Ilmiah Mahasiswa FEB Universitas Brawijaya, 3 (23).

Wu, C.Y. and Chung, C.P. (2016). The Effects of Store Atmosphere and Sales Promotion on Purchase Intention -Perceived Customer Mood as a Mediator. Business Research Review 2 (1), pp: 33-50

Yistiani, Ni Nyoman Manik., Yasa, Ni Nyoman Kerti., dan Suasana, I.G.A Ketut Gede. (2012). Pengaruh Atmosfer Gerai dan Pelayanan Ritel Terhadap Nilai Hedonik dan Pembelian Impulsif Pelanggan Matahari Department Store Duta Plaza di Denpasar. Jurnal Manajemen, Strategi Bisnis, dan Kewirausahaan, 6 (2), pp: 139-149.

Yudha, I Putu Manik Kartika dan Suprapti, Ni Wayan Sri. (2018). Pengaruh Atmosfer Toko dan Daya Tarik Promosi Penjualan Terhadap Kepuasan Pelanggan dan Niat Beli Ulang (di Matahari Mall Bali Kuta Galeria Kuta). E-Jurnal Ekonomi dan Bisnis Universitas Udayana. 7 (7), pp:1803-1834.

Yulianti, Ni Made Dhian Rani, Suprapti, Ni Wayan Sri, Yasa, Ni Nyoman Kerti, (2014), Pengaruh citra toko terhadap kepuasan pelanggan dan niat beli ulang pada Circle K di Kota Denpasar, Matrik: Jurnal Manajemen, Strategi Bisnis dan Kewirausahaan, 8 (1), pp. 36-44. 